\title{
Research Paper An economic study of Prayagraj markets and Lucknow market for banana : Arrival and price stability
}

\section{Setu Ratnam and Sanjay Kumar}

See end of the paper for authors' affiliations

Correspondence to :

\section{Setu Ratnam}

Department of Agricultural Economics, Sam

Higginbottom University of Agriculture, Technology and Sciences, Allahabad (U.P.) India

Email: seturatnam@gmail. com

\section{Paper History :}

Received : 18.06.2020;

Revised : 18.07.2020

Accepted : 20.08.2020
ABSTRACT : Arrival in an existing market is major referral point for price determination in perishable agricultural commodity, this paper shows a comparative analysis of arrival, wholesale and retail price and their dependency and their stability in the banana marketing system. The two markets under consideration are Lucknow and Prayagraj wholesale markets. The information is collected from Mundera Mandi in Prayagraj and from APEDA site for Lucknow market. A trend analysis was done to access the market arrival and pricing accordingly, a significant relationship has been obtained and the overlapping seasonality of the fruit in the two market gives viable description about demand existence at different time zone in the year and thus exploitation of the wholesale market by the local growers.

KEY WORDS : Trend, Seasonal components, Arrivals, Prices

How To Cite This Paper: Ratnam, Setu and Kumar, Sanjay (2020). An economic study of Prayagraj markets and Lucknow market for banana : Arrival and price stability. Internat. Res. J. Agric. Eco. \& Stat., 11 (2) : 212-216, DOI : 10.15740/HAS/IRJAES/11.2/212-216. Copyright@2020:Hind Agri-Horticultural Society. 